\title{
Rice research and development in West Africa: Problems and perspectives
}

\section{H. A. Luning}

Department of Land Resource Surveys and Rural Development, International Institute for Aerial Survey and Earth Sciences (ITC), P.O. Box 6, 7500 AA Enschede, Netherlands

Accepted: 19 June 1984

Key-words: rice research and development, West Africa, constraints, research allocation

\section{Summary}

This paper addresses itself to problems and perspectives of rice research and development in West Africa. The place of the rice economy in West Africa and its development since the $1960 \mathrm{~s}$ is focussed on. Its disappointing performance is reviewed within the context of West Africa's overall food problems. Rice research and development in West Africa is sketched, broken down according to major agro-ecological zones. Constraints and potentials are discussed and the question is posed why returns to rice research are so insignificant. Finally, the perspectives of improved research allocation and productivity in regional rice research are discussed.

\section{Introduction}

In the last two decades, significant steps have been taken in narrowing the agricultural technology gap among countries. Since the early 1960 s a set of international agricultural research centres have been established and in a number of low-income countries substantial progress has been made in strengthening national agricultural research capacity. However, this development seems to have largely bypassed Subsaharan Africa. The foundation of a regional rice development institute for West Africa in 1971 has not led to rice production increases, which occurred for instance through the efforts of the International Rice Research Institute (IRRI) in the Philippines.

\section{The role of agricultural research in agricultural development}

Ever since Griliches' study on research costs and returns of hybrid maize in the USA (1958) there has been a proliferation of studies which indicate that returns to investments in agricultural research have been high. As has been pointed out dur- 


\section{H. A. LUNING}

ing an international conference on resource allocation and productivity in agricultural research (Arndt, Dalrymple \& Ruttan, 1977) the evidence at hand about returns to these investments are sufficiently robust (in general internal rates of return, IRR, between 20 and $90 \%$ ) to warrant the conclusion that agricultural research productivity can be high. However, returns can be low too, as studies on wheat and cotton research in Colombia (Hertford et al., 1977) show. Qualitative evaluations of much local agricultural research activities concur and a picture emerges that research returns are very variable indeed. Why this is so, is not always very clear. It could be argued that the high pay-off in the studies on agricultural research productivity is limited to a selected number of success stories and that much of the research in low-income countries has not been very productive. We will take up this matter in the discussion of rice research in West Africa.

\section{Rice in the economy of West Africa, 1960-1983}

\section{West-Africa's food problems}

Defining the 'lowest income' countries as those with per capita annual incomes of less than \$ 360 the 1983 World Bank Atlas shows that in mid 1980 nine out of fifteen West African countries belonged to this category. Average real annual growth of GNP during the 1970 s has been low with zero (less than $0.5 \%$ ) and negative growth rates in eight out of these fifteen countries. Only in Nigeria and in the Gambia did the average growth rate of agriculture exceed the growth rate of population during the period 1970-80; at present this is the case in none of the West African countries. The reasons given for this disastrous state of affairs are by now quite well documented. Drought during the 1970 s no doubt was a major factor in some years. As Eicher (1982) has pointed out: 'The crisis stems from a seamless web of political, technical and structural constraints which are a product of colonial surplus extraction strategies, misguided development plans and priorities of African states since independence, and faulty advice from many expatriate planning advisers ....' Farmers have received little or no incentives and there has been a neglect of building rural institutions serving the peasantry. Africa's inability to feed itself - with so much unused land and relatively high levels of foreign aid - is one of the major paradoxes on economic development (Eicher, 1982).

Food imports (mainly wheat and rice) have increased in Africa from 1.2 million tonnes a year in 1961-63 to 8 million tonnes in 1980, and commercial imports of food grains grew more than three times as fast as population over the period 1961-79. These steeply rising food imports are attributed to a number of factors: lagging domestic production and increasing urbanization. For example, in Nigeria urban population increased from 7.0 million ( $13.8 \%$ of total population) to 17.7 million $(20.9 \%)$ between 1960 and 1980 , in Ivory Coast it increased from $21 \%$ to nearly $36 \%$ of the total population over this period. This brought with it a shift of consumer preferences from the traditional roots and tubers, sorghum, millet and maize to wheat (bread) and rice. In addition, food aid has been substantial in many countries. Overvalued foreign exchange rates in several instances make imported cereals cheaper than domestic production. The last two issues, in addition to low producer 
prices, have certainly diminished incentives (both at national and at farm level) to produce more of the local staple foods.

Rice in West Africa

Approximately 340 million tonnes of rice are produced on 145 million hectares in the world to-day. Developed countries (Japan, USA, etc.) account for about $2 \%$ of the total area, Latin America for almost $5 \%$, developing Asian countries for about $90 \%$. Africa contributes $3 \%$ of the world's rice area, of which West Africa accounts for about half.

Rice in West Africa is cultivated under greatly varying smallholder farming and cropping systems as Table 1 shows. Upland rice accounts for $65 \%$ of the area. It is mainly grown by smallholders either under shifting cultivation (bush fallow) in high rainfall areas (Liberia) or under hydromorphic conditions which fluctuate between flooded, saturated and upland conditions within a season (Moormann \& Veldkamp, 1978, Buddenhagen, 1978). The hydromorphic type is prevalent in Nigeria and Ghana. Most other rice in the region is grown under either mangrove conditions or in inland valley swamps without water control. Table 1 shows that irrigated rice covers only a very small proportion of total rice acreage.

Rice is mostly cultivated by smallholders but its importance within farming systems varies greatly within the region and even within ecosystems. With the exception of some irrigated projects (e.g. Office du Niger, Mali) where mechanization or animal traction is practised, most rice farming is carried out manually.

Labour utilization is thus very high, compared with rice under many cropping systems in South and Southeast Asia. In countries like Taiwan, Thailand, Phil-

Table 1. Classification and inventory of rice cultivation types in West Africa.

Percentage of total paddy area (1976)

1. Upland rice cultivation

1.1. Strictly upland cultivation

1.1.1. Hill rice

1.1.2. Flatland rice

1.2. Groundwater cultivation with rains

1.3. Groundwater cultivation without rains

2. Lowland rice cultivation

2.1 Mangrove rice cultivation

2.1.1. Without tidal control

2.1.2. With tidal control

2.2 Freshwater cultivation

2.2.1. Without water control

2.2.2. With partial water control

2.2.3. With complete water control
65

62.5

$\begin{array}{ll} & 57.5 \\ 2 & 2 \\ 0.5 & 0.5\end{array}$

35

8
27

6

22

3

2

$\begin{array}{llll}\text { Total } & 100 & 100 & 100\end{array}$

Source: Types of rice cultivation in West Africa. Occasional Paper No 2. WARDA, July 1980, pp. 2223. 


\section{H. A. LUNING}

ippines and South Korea the number of man/woman-days per hectare of (irrigated) rice lies in the order of 80-120 (Barker \& Cordova, 1978); in West African mangrove rice farming it is in the order of 400 man-days/ha or even more (WARDA, 1983 ${ }^{\text {; }}$, de Jonge et al., 1978). The contrast is much larger when looking at labour productivity. With yields of on average $3.5 \mathrm{t} / \mathrm{ha}$ in irrigated areas of $\mathrm{S}$. and $\mathrm{S}$.E. Asia, the gross productivity per day of work is $35 \mathrm{~kg}$ of paddy whereas at yield levels of $1.2 \mathrm{t} /$ ha in $\mathrm{W}$. Africa the labour productivity is only $3 \mathrm{~kg}$ of paddy per man-day. This is in line with studies quoted by Ruthenberg (1980) from Sierra Leone, Liberia and Ivory Coast. The labour productivity expressed in $\mathrm{kg}$ padi per man-day was 3.8 , 2.8 and 4.5 , respectively. Thus, gross labour productivity in rice cultivation is about ten times as high in a number of South and Southeast Asian countries compared with the West African situation.

Table 2 gives an overview of the importance of rice production, consumption and imports, which have been increasing steadily over time in most West African countries.

In 1960/64 1.5 million hectares were planted to rice in the 15 countries together. By 1980/82 this area had increased to 2.5 million hectares. Production increased at the same pace as there was little change in yields per hectare. Imports were 0.3 million tonnes in 1960/64, 0.9 million tonnes in $1975 / 79$ and 1.7 million tonnes in 1981 and 1982. These recent imports account for about $13 \%$ of world rice imports while in the 1960 s the region took about $5 \%$ of world imports.

The rapid increase of imports is largely attributed to large consumption increases. Average per capita consumption was about $12 \mathrm{~kg}$ in $1960,15 \mathrm{~kg}$ in 1975 and increased to $23 \mathrm{~kg}$ in 1982 . For 1983 the per capita rice consumption is expected to level off or decrease because of foreign exchange problems which curtail imports. Regional self-sufficiency in rice which stood at over $70 \%$ in $1970 / 74$ has dropped to $48 \%$ in $1980 / 82$. None of these countries is presently self-sufficient in rice. The large rice importers are Nigeria, Senegal, Ivory Coast, Liberia and Guinea, which accounted for $82 \%$ of West African rice imports in 1982. Since 1980 there has been no significant amount of stocks carried over from year to year (with the exception of Senegal and Gambia). An interesting pattern of rice consumption can be observed. Per capita annual rice consumption is at Asian levels (90-120 kg) in Liberia, Sierra Leone and recently also in Gambia. Ivory Coast, Guinea, Guinea Bissau, Mauritania and Senegal form a middle group consuming annually $50-70 \mathrm{~kg} / \mathrm{head}$. In the remaining countries, consumption levels are far lower.

Population has grown over the last five years by approximately $14 \%$, total paddy production has increased by $8 \%$ and per capita rice consumption by about $20 \%$. The ultimate outcome is that the gap between consumption and production has substantially widened over this period. Rapid increase in rice consumption can be attributed to population and (sometimes) income growth and to urbanization, which has generally led to a substitution of other cereals by rice. To this should be added the heavy subsidizing of consumer or retail prices which has made rice one of the cheapest foods consumed in many West African countries. This is illustrated with the case of Ivory Coast where rice prices increased by $130 \%$ between 1960/66 and $1976 / 77$ while other staple food prices increased by 180 to $360 \%$ (Pearson et al., 


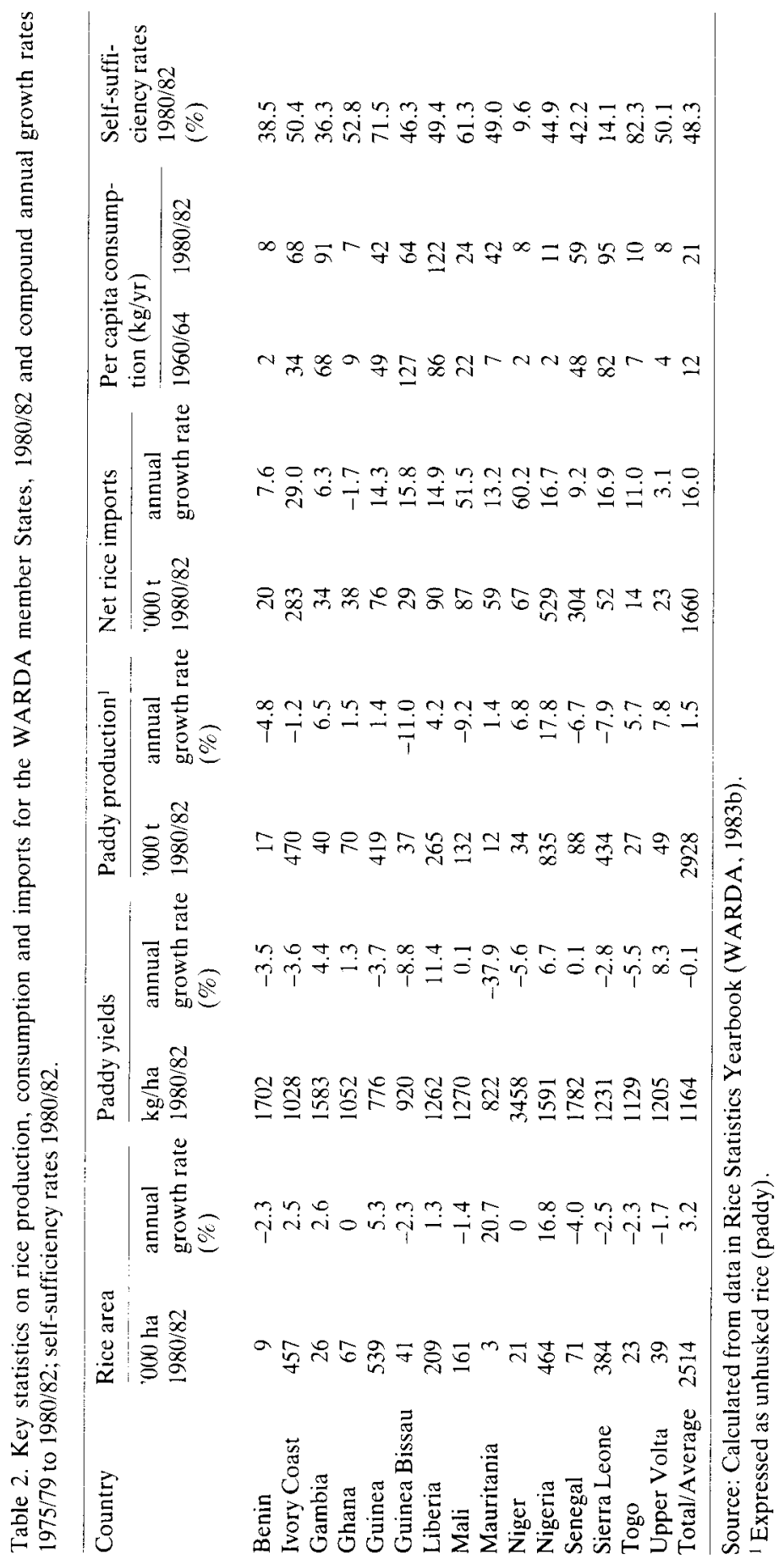

Neth. J. agric. Sci. 32 (1984) 
1981). However, the decreasing ability of Governments to maintain subsidies must lead to a gradual increase in consumer prices, unless substantial food aid or production increases can offset this price trend. So far the extent of consumer price increases has not had much effect in slowing down demand for rice.

Production incentives to farmers vary from country to country. All West African countries operate guaranteed producer price schemes aimed at providing economic incentives. These guaranteed prices increased in most countries since 1975/79. However, they remained constant in Nigeria, Niger and Senegal and were reduced in Ivory Coast where price setting of rice (and fertilizer) has been rather erratic over the last few years. A change in producer prices would, 'all other things being equal', affect land cultivated and possibly yield, hence output. However, there are two major sets of factors which mitigate this effect. Firstly, in many subregions farmers produce rice primarily to meet their subsistence need. Though price differences between foods which are substitutes in the diet have an effect on production decisions, these effects may be rather small. Secondly, and probably more important are the many constraints faced by the farm family in rice production: soil and water problems, lack of seeds and other inputs, pests and diseases, labour shortages, infrastructure, lagging post-harvest technologies and marketing bottlenecks, which lead to a situation where farmers often have to accept low ex-farmgate prices.

It is not possible here to go beyond an inventory of major constraining factors. It should be pointed out that their relative importance varies from location to location, as will be shown below. In fact, no systematic research under farmers' conditions has been carried out in West Africa, until very recently. The West African savanna soils are notably difficult to improve (see Jones \& Wild, 1975). It appears that improved land productivity cannot be expected for a large part to stem from improved varieties, as was the case in Asia's green revolution. There are strong indications that the physical environmental factors are overwhelmingly important and ready solutions are not in sight. More will be said about these factors in the following paragraph.

Over-valued exchange rates may also negatively affect rice production. Lack of foreign exchange greatly affects mechanized rice cultivation and pump irrigation; this has been so in Ghana, Mali and the Gambia in recent years. In a number of irrigation schemes the insecurity of land tenure plays a role. Farm credit plays a modest role because use of cash is limited. In the 1981/82 season, the Ivory Coast Government introduced a farm credit policy requiring a $20 \%$ down-payment before inputs can be purchased on credit. In Senegal in the same season, the Government directed public agencies providing seasonal farm inputs to deliver on cash basis only. In both countries there appears to have been a negative effect on chemical input use and hence on yields and output.

The Government's policy to promote domestic rice production is reflected in the official prices paid to producers. These prices include a varying subsidy to producers. Table 3 shows these average prices for the period 1980-82. Fluctuations are very large indeed. In Mali the governmental rice price policy leads to an outright squeeze. A two-year study in the Office du Niger (a large irrigated rice production 
Table 3. Official paddy producer prices in US \$ per $\mathrm{kg}(1980-82)$.

\begin{tabular}{llll}
\hline Country & 1980 & 1981 & 1982 \\
Benin & 0.19 & 0.17 & \\
Gambia & 0.27 & 0.26 & 0.23 \\
Ghana & 1.27 & 1.97 & 2.45 \\
Guinea Bissau & 0.25 & 0.24 & $\cdot$ \\
Ivory Coast & 0.31 & 0.18 & 0.40 \\
Liberia & 0.26 & 0.40 & 0.18 \\
Mali & 0.15 & 0.14 & 0.24 \\
Mauritania & 0.22 & 0.26 & - \\
Niger & 0.21 & 0.18 & - \\
Nigeria & 0.60 & 0.56 & 0.17 \\
Senegal & 0.20 & 0.19 & $\cdot$ \\
Sierra Leone & 0.26 & 0.30 &. \\
Togo & 0.28 & 0.26 &. \\
Upper Volta & 0.30 & 0.25 & \\
\hline
\end{tabular}

Source: WARDA, 1983b.

scheme in Mali) in 1980 and 1981 showed that it costs farmers 83 Malian francs to produce $1 \mathrm{~kg}$ of paddy. However, the government paid only 60 Malian francs per $\mathrm{kg}$ (Kamuanga, 1982). This was in sharp contrast with neighbouring countries such as Senegal, Niger and Upper Volta where prices paid to farmers amounted to the equivalent of 108 to 128 Malian francs. In a study on rice in West Africa (Pearson et al, 1981), covering Mali, Sierra Leone, Liberia, Senegal and Ivory Coast, it is shown that domestic rice production is only justified for on-farm and in-village consumption. Outside Mali and Sierra Leone (out of the five countries studied) rice production to replace imports in urban areas is unprofitable from a socio-economic viewpoint with existing technologies. In other words in many countries it would be cheaper to import rice than to produce it domestically.

\section{Rice research in West Africa}

Rice research in West Africa started 60 years ago in Moor Plantation, Ibadan, Nigeria (ILRI, 1983). The oldest rice research station in West Africa is Rokupr in Sierra Leone (1934). In the 1950s several rice research stations were founded: in Nigeria, Ghana, Liberia and the Gambia. With the establishment of the International Agricultural Research Centres (IARC) a new dimension was introduced. IRRI has a world-wide mandate for rice and IITA (Ibadan, Nigeria), which started in 1967, has an important rice improvement programme as well. Mention should be made of the rice research carried out by IRAT in Ivory Coast.

In 1971 the West Africa Rice Development Association (WARDA) started its operations. Though it is a member of the CGIAR it is different in many ways from other IARCs. It is governed by fifteen member states which elect the top management and provide a cash subscription to the total budget of WARDA. Its activities encompass both research, development and training. The Association assists the 
governments of member states to increase rice production and rice marketing efficiency.

Formal and informal agreements on close planning of programme implementation, recognizing the complementarity of the inputs of each organization, have been made between IITA, IRRI, WARDA and IRAT and with national research systems. WARDA's research role in developing and extending improved varieties and practices is primarily that of an intermediary among the national programmes of its member states and between national programmes and regional/international organisations.

Partially because of a general paucity of information on West African rice-based cropping/farming systems much of the rice research and development has followed conventional lines with major emphasis on improving yields per acre with the use of high-yielding varieties (HYV) and chemicals.

From the start in the early 1970 s one was optimistic about transferring the technology generated at the IARCs (particularly IRRI) to the national programmes. It was thought that HYVs plus other inputs could substantially improve rice production in the region. Hence, much has been invested in coordinated variety trials. In 1978 the WARDA first Quinquennial Review (Q.Q.R.) recommended that this programme be continued and consolidated. Five years later it has become evident that constraints are many to adopt new varieties, which are often ill-suited to prevailing farming conditions characterized by seasonal labour bottlenecks, poor or no water control, poor or non-existent input delivery systems, lack of efficient extension, and seed production programmes and involving farmers with strong tendencies (rightly so!) to risk aversion.

West African farming systems are very variable and complex and it is apparent that information on climate and soils in many localities is not available or fragmentary (2nd Q.Q.R., WARDA, 1983c). The adoption of recommended varieties has been very uneven throughout the region and estimates of the spread of these recommended varieties suggest that they are not grown widely. So far, there has been no magic variety! (USAID, 1983).

A systematic constraint analysis of rice-based cropping systems in the various agro-ecological (sub-)zones in West Africa is fragmentary. Moreover, the relationship between rice production and other farm enterprises in terms of allocation of resources at farm level often become of critical importance in determining whether recommended improved practices will be accepted. The commodity approach (e.g. rice) may be quite narrow in farming systems where the particular commodity is only of secondary importance as is true perhaps of most West African rice farmers.

An important step has been the establishment of four special research projects in WARDA's programme which represent four major agro-ecological zones: mangrove swamp rice (Rokupr, Sierra Leone), upland rice (Bouaké, Ivory Coast), deep water/floating rice (Mopti, Mali), irrigated rice (Richard Toll, Senegal). In all four sites research is not restricted to the experimental fields of the station but has been extended to farmer's fields near the station as well as to areas in member countries with similar climatic and soil conditions.

The mangrove rice station in Sierra Leone is typical of those coastal parts of West 
Africa where the rainfall is high and rice can be grown along the rivers that flow into the sea. The plant type of the improved varieties is not far different from that of the traditional varieties, which have a tolerance to crabs and to high levels of soluble iron, saline soils and varying levels of flood water encountered in the tidal swamps.

The upland rice station in Ivory Coast is typical of the savannah ecology where annual rainfall ranges between 1000 and $1200 \mathrm{~mm}$. Area-wise upland rice is the most important rice crop; a proportion of it is grown under shifting cultivation under relatively high rainfall (over $2000 \mathrm{~mm}$ ). Yields are low and disease, weed competition, decreasing soil fertility, birds and rodents take their toll.

The deep water/floating rice site in Mali is representative of large areas along the Niger River and its tributaries. However, the question arises after three years where floods failed or came too late $(1981$, '82, '83) whether the levels of the Niger River at flood crest are continually getting lower. If so, then it becomes less likely that the potential 500000 ha in these river valleys can be flooded and become usable for deep water rice production.

The Senegal station represents the more arid parts of the region. Areas with good water control have the largest potential for increasing rice production with high and stable yields. Major issues are: choice of varieties with cold and (desiccating) wind tolerance, soil and crop management practices and control of insects and diseases.

WARDA became aware in the 1980s of the need to test the appropriateness and economic attractiveness of its technologies and this led to the establishment of the Technology Assessment and Transfer (TAT) programme. It combines certain aspects of yield constraints research with farming systems research. It involves a pooling of a priori knowledge with survey information obtained from farmers and from the technology design activities to specify particular technology packages for defined environments. These technologies are applied in farmers' fields with farmers' participation and evaluated economically. When appropriate technologies have been identified they are demonstrated cooperatively by WARDA and local agricultural extension officers. So far these activities are carried out for the mangrove swamp ecology and for deepwater/floating rice since 1981/1982, followed in upland rice and irrigated areas in 1983.

This programme, the impact whereof cannot as yet be measured, appears to have the potential for agricultural research programmes, designed to produce results which are more useful, relevant and acceptable to farmers. The impact of a new technology is not just measured by its yield level in experimental plots but by the extent to which it is adopted by the farmers. Surrounded by so many constraints, the farmer has to make decisions which encompass limited resources, time constraints, adverse conditions from land preparation to marketing and risks. Technology assessment is particularly important where institutional links (e.g. extension) are weak. Thus this concept has to work both on assessing improved technology within the farmers' decision-making framework and on testing an extension education strategy. Presently it is too early to measure its impact after only one to two years after implementation.

The complexity of rice-based farming systems is evident from the limited number of farm studies carried out in West Africa and this is not confined to physical and 
biological aspects only. For example, the division of labour between men and women among several tribes in Gambia is that women cultivate rainfed and tidal rice, having user rights to rice land, whereas men grow upland crops, i.e. sorghum, millet, groundnuts (de Jonge, 1978; Dey, 1981). This has its ramifications as for example in the introduction of new technologies (irrigation, mechanization): women are gaining far less than men and social consequences of new rice technology can be profound (Dey, 1981).

Upland rice with its greatly diverse appearance (ranging from hills to hydromorphic soils) is a badly neglected crop as regards research and development, not just in West Africa only. It is low yielding with lack of drought resistance and vulnerability to blast as major weaknesses.

Dallard (1983) has pointed out that few publications are on upland rice; in going over 10 issues of Plant Breeding Abstracts (1982) he found only 28 publications, compared with 160 for a crop such as Triticale and 128 for rye. Rye covers worldwide $15 \times 10^{6}$ ha, for upland rice the cultivated area is $16 \times 10^{6}$ ha in total. Upland rice did not have a separate sub-heading in the Journal. He furthermore illustrates the rather primitive character of upland rice in comparing the amount of grain (in $\mathrm{kg}$ ) produced per $\mathrm{kg}$ of nitrogen applied:

Upland Rice (IRAT-13, Ivory Coast)*: $17 \mathrm{~kg}$ grain $/ \mathrm{kg} \mathrm{N}$

Irrigated rice (IRRI varieties): $25-30 \mathrm{~kg}$ grain $/ \mathrm{kg} \mathrm{N}$

Wheat (European farm conditions): $30-35 \mathrm{~kg}$ grain $/ \mathrm{kg} \mathrm{N}$

If the assumption is correct that from a genetic point the upland rice is close to irrigated rice, than the potential for increased yields due to varietal improvements seems to be promising.

After the foregoing it will be evident that returns to rice research in West Africa are low and often have been zero. In fact, there has been little or no impact of this research at farm level.

Identification of problems is a useful first step but one should now establish the relative importance of the various issues in the major agro-ecological zones. Upland rice needs further subdivision according to rainfall and location in the landscape. Moreover, it is very well to point at inadequate mechanization and credit facilities, but the economics of it are not encouraging. With regard to land preparation, it is economically unattractive for the average upland rice farmer in West Africa to purchase a power tiller and in the wetter areas no draft animals exist. As long as land and labour productivity for rice remain so low no major change can be expected.

\section{Perspectives}

It is extremely difficult to chart the possible courses of rice research and development in West Africa. One of the hardest nuts to crack is still the general problem of permanent land use in the humid tropics, particularly of annuals on non-flooded land (Ferwerda, 1980). A concerted effort is required to conduct research designed

* Already an improved variety compared with local varieties in converting $\mathrm{N}$ more efficiently into grain. 
to develop a permanent system of soil and crop management to increase rice production in the wet forest zone of West Africa, which represents a large acreage under rice.

In the lower rainfall areas, particularly in the Guinea Savanna belt one wonders why sorghum, millet and maize are not given priority by the farmers. Two reasons can be given: firstly, no major breakthrough has been attained in the breeding of these three cereals in West Africa; yields are still low. Secondly, the food preferences and easier food preparation makes rice (and bread) more popular with the rapidly growing urban masses.

For most rice-based cropping systems in West Africa a well-tested technology package does not as yet exist. Technology which was succesful in Asia (the spread of IR 36 and 52, Mexi-Pak wheat, etc.) is not easily transferred to West Africa. Asian ecological conditions (particularly soils), factor endowments and institutional settings are so different. The major vehicle for identifying specific constraints appears to be the Technology and Transfer (TAT) programme, rather than coordinated trials. However, TAT has just started. 'Recommendation domains' (which refer to groups of farmers whose agricultural and socio-economic circumstances are sufficiently similar that they will adopt the same recommendation, given equal access to information) have to be identified and delineated first, prior to the design of on-farm research. As has been experienced in on-farm research, the various problems should be presented as much as possible as researchable components. As was pointed out above, these components are not restricted to the agronomy of rice but cover a whole and varying range of technical, biological and socio-economic issues.

A crucial issue appears to be research management. The potential of the rice research programmes (and also for other staple foods) in West Africa over the last decades has not been fulfilled because no clear view of the total research and development process has been crystallised in many of these agricultural research institutes.

\section{Acknowledgement}

I like to thank Prof. Dr Ir T. M. Wormer and an anonymous reviewer for critical comments on a draft of this paper.

\section{References}

Arndt, T. M., D. G.Dalrymple \& V. W. Ruttan, 1977. Resource allocation and productivity in international research. University of Minnesota Press, Minneapolis.

Barker, R. \& V. G. Cordova, 1978. Labor utilization in rice production. In: Economic consequences the new rice technology. IRRI.

Buddenhagen, I. W., 1978 Rice ecosystems in Africa. In: I. W. Buddenhagen \& G. J. Persley (Ed.), Rice in Africa. Academic Press, London.

Dallard, J., 1983. Le riz pluvial. Passé et perspectives. Revue Quinquenniale de l'ADRAO, Bouaké, Cote d'Ivoire, Septembre.

Dey, J., 1981 Gambian women: Unequal partners in development projects? Journal of Development Studies $17(3)$.

Eicher, C. K., 1982. Facing up to Africa's food crisis. Fall. Foreign Affairs.

Neth. J. agric. Sci. 32 (1984) 


\section{H. A. LUNING}

Ferwerda, J. D., 1980. Problems of permanent land use in the humid tropics. Wissenschaftliches Zentrum Tropeninstitut, Giessen.

Griliches, Z., 1958. Research costs and returns: Hybrid corn and related innovations. Journal of Political Economy 66 (October).

Hertford, R., J. Ardila. A. Rocha \& C. Trujillo, 1977. Productivity of agricultural research in Colombia. In: T. M. Arndt, D. G. Dalrymple \& V. W. Ruttan, Resource allocation and productivity in international research. University of Minnesota Press, Minneapolis.

ILRI, 1983. Wetland Utilization Research Project, West Africa. April.

Jones. M. J. \& A. Wild. 1975. Soils of the West African Savanna. C. A. B. Technical Communication 55. Commonwealth Agricultural Bureaux, Slough, England.

Jonge, K. de, J. van de Klei, H. Meilink \& R. Storm, 1978. Les migrations en Basse Casamance (Sénégal). Afrika Studie Centrum. Leiden.

Kamuanga, M., 1982. Farm level study the rice production system at the Niger in Mali: An economic analysis. Ph. D. Dissertation, Dept. of Agricultural Economy, M.S.U., Michigan.

Moormann, F. R. \& W. J. Veldkamp, 1978. Land and rice in Africa: Constraints and potentials. In: I. W. Buddenhagen \& G. J. Persley (Ed.), Rice in Africa. Academic Press, London.

Pearson, S. R., J. D. Strijker, C. P. Humphreys et al., 1981. Rice in West Africa. Stanford University Press.

Ruthenberg. H.. 1980. Farming systems in the tropics. Clarendon Press, London.

USAID, 1983. West Africa rice research and development, USAID Project Impact Evaluation Report No 44, May.

WARDA, 1979. Report of the TAC Quinquennial Review Mission to WARDA. FAO.

WARDA, 1980 Types of cultivation. WARDA occasional paper, July.

WARDA, 1983a. T.A.T. Programme. Part A. Preliminary analysis of socio-economic baseline data. Annual Rice Research Meeting, May.

WARDA, 1983b. Rice statistics yearbook. June.

WARDA, 1983c. Draft report of the external programme review of WARDA, October.

World Bank, 1983. World Bank atlas. 